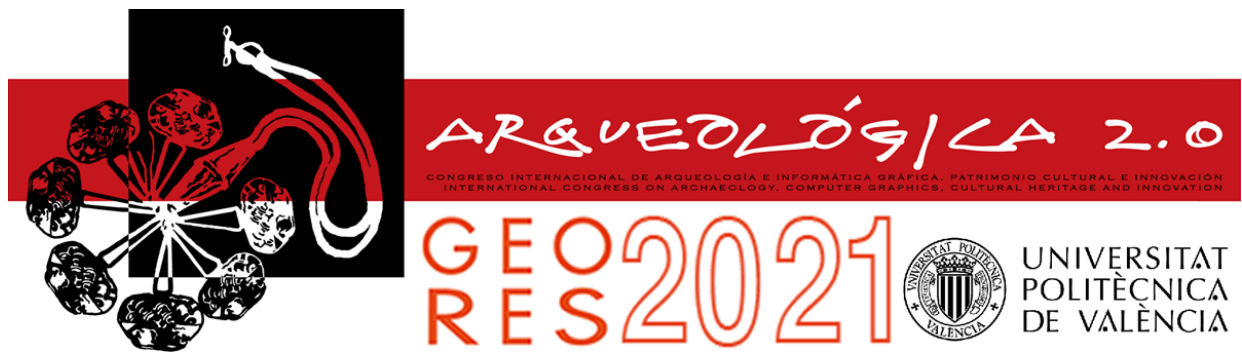

Proceedings of the joint international event $9^{\text {th }}$ ARQUEOLÓGICA

$2.0 \& 3^{\text {rd }}$ GEORES

Valencia (Spain).

26-28 April 2021

\title{
MENSIOCHRONOLOGICAL TECHNIQUES FOR TIMBER ELEMENTS: LIMITS AND SPECIFICITIES THROUGH A CASE STUDY
}

\author{
Alberto Grimoldi, Angelo Giuseppe Landi, Emanuele Zamperini* \\ Department of Architecture and Urban Studies, Politecnico di Milano, Via Bonardi 3, 20133 Milan, Italy. alberto.grimoldi@polimi.it; \\ angelogiuseppe.landi@polimi.it; emanuele.zamperini@polimi.it
}

\begin{abstract}
:
In Italy, studies on wooden structural elements in masonry buildings, from the Middle Ages throughout the Modern Age to the twentieth century, are few in number compared to other European countries and present a less systematic approach. It is necessary to carry out progressively, but systematically, highly-detailed surveys and to correlate them with the existing discontinuous documentation. Diachronic comparisons - referring to significant geographical areas in which evident constructive constants are recognizable - would highlight the variation over time of the models and their diffusion, while the comparison, especially synchronic, between solutions evidently different or apparently similar, would allow to better understand both the constructive choices and their static behaviour. The application of mensiochronological techniques to the analysis of timber structures, especially floors, is an interesting and promising field of research. The significant measures for dating are various: dimensions and centre distances of beams and joists, width and thickness of the boards, the dimension of the accessory elements (e.g. joint laths), but the variety of construction techniques often makes it difficult to identify comparable measures. In addition, the working processes and tree species have a decisive impact on the measures of the artefacts. Mensiochronological techniques usually detect slow but evident variations; however, a centuries' old constancy is equally significant. More general information about the context is useful, in particular which choices are not determined by mere technical reasons. A better historical knowledge serves to understand the qualities and limitations of existing structures, and the features - including decay - in which they appear. The floors of Palazzo Magio in Cremona, dating from the fifteenth century to the end of the eighteenth century, allow reflecting on how and what to examine.
\end{abstract}

Keywords: timber floors, historic construction techniques, mensiochronological analysis, Palazzo Magio in Cremona

\section{From bricks to timber: limits of mensiochronological techniques}

Mensiochronology is an analytical technique aimed at correlating the dimensions of a given element to its absolute dating. This technique has developed since the 1970s, focusing especially on brick elements, for which for some time it was already known that the measures had varied over centuries, following the transformations of the technique, of the production methods, and of the social relations underlying them (Mannoni \& Milanese, 1988; Pittaluga, 2009). After the first enthusiasm, the idea of creating a mensiochronological "curve" - similar in many respects to the dendrochronological curves - necessarily had to deal with individual places and individual historical circumstances (Landi, 2013).

Timber also has recurring measures, linked to its specific characteristics, and the practice of re-use is widely documented, as for bricks. Therefore, we can ask ourselves if, in what way, and within what limits, the metric data of the various artefacts - in particular of the wooden floors - can at least partially flank dendrochronology in dating.
In particular, for which time intervals the measures of wooden elements did not undergo significant variations? The constancy of measures over long periods - as often happens also for bricks - isn't less significant than a relatively frequent variation, which intuitively allows easier dating.

More so than bricks, wooden artefacts have their own particularities. As in dendrochronology, the species is relevant, since it affects the size and shape of the elements. However it is also essential to take into account the entire production process, from cutting and trading of logs and sawn timber, to their processing before and during construction site operations.

As a consequence, another question arises: which measures are significant, and how to acquire and record them? In the study of the floors, the measures that can be considered as significant quantities for dating are various: dimensions and centre distances of girders and joists, width and thickness of the boards, the dimension of the accessory elements (e.g. joint covering laths).

An attempt at an answer also involves direct verifications and case studies. 


\section{Studies on timber floors}

The bibliography on timber floors in masonry buildings is extensive, even if systematic studies are lacking, especially in Italy. Most of the research focuses on technological and typological features of timber floors of a specific geographic area and are often limited to analyzing the proportions of the elements and their centre distances. The topic of dimensions is generally treated only marginally, with generic references to the commercial measures of timber elements and often providing very wide and, therefore, not very significant dimensional ranges. Among some research, that of Emilien Bouticourt is particularly significant, because it follows the genesis of carpentry from the cutting of the timber and the woodworking, to the realization of the structure, floor or roof, highlighting all the conditions that influence it (Bouticourt, 2016); in particular, he analyzes nine examples of floors made in an interval of 100 years, reporting the average section and centre distance of the joists. Instead, no research deals systematically with the measurements of the wooden floors to evaluate the possibility of using them for dating the analyzed artefacts.

\section{Cremona and its timber structures: a short season between the $15^{\text {th }}$ and the $17^{\text {th }}$ centuries}

Cremona is famous for some of its wooden artefacts, not only for its luthier production - from the $16^{\text {th }}$ century to the early $18^{\text {th }}$ century, disappeared and restarted in the last half-century - but also for its wooden sculpture. Timber roof structures and floors, partly surviving, are also of great interest, albeit little known. The recurring wood is oak, as happens in the heart of the Po Valley, going up the river Po from Cremona; downstream, the floating of the logs and the large market in Verona make conifer wood from the Adige valley easily available (Dandria, 2010).

However, only the best-finished artefacts can show significant dimensional recurrences, since, in the works of lesser quality, builders used what was easily available; even the choice of timber could vary, using less dense and resistant species, like poplar and alder.

The only existing studies - Floriana Petracco's doctoral thesis (Petracco, 1998) - also report imports, when demand cannot be satisfied by local production. However, the inflow does not appear to be constant or systematic.

The wood comes from Emilia via river, or from Brescia, a city to which the road was already vehicle accessible at the end of the $15^{\text {th }}$ century, from which spruce wood was imported (Petracco, 2011). However, it seems that the use of coniferous wood was limited to boards, since the mining industry - with its demand for both coal and firewood - was a formidable competitor.

The Palazzo Magio (Landi, 2011) - where the surveys that inspire these considerations were carried out - is a sort of sample case of the most common timber floors in the city (Grimoldi, Landi, \& Facchi 2019; Figs. 1-3). The building is the result of the unification of four pre-existing houses into a large patrician residence, of which decorative and structural elements have often been preserved. On the ground floor, in the west wing there is a very elaborate double frame floor - datable to the late $15^{\text {th }}$ century - with girders and joists on corbels, and double bussole (small boards) flat and vertical between the joists and concave - typical of the city and of the countryside of Cremona - between the corbels (Figs. 4 and 5). Upstairs, in the corresponding rooms, only the sequence of the main beams remains from the same phase. Joists and planking were integrated and reassembled or replaced in the second half of the $17^{\text {th }}$ century or in the first decades of the following, when Giuseppe Natali (Biffi, 1988) painted the decoration of the room (Baroni \& Travaglio, 2011) (Figs. 6 and 7).

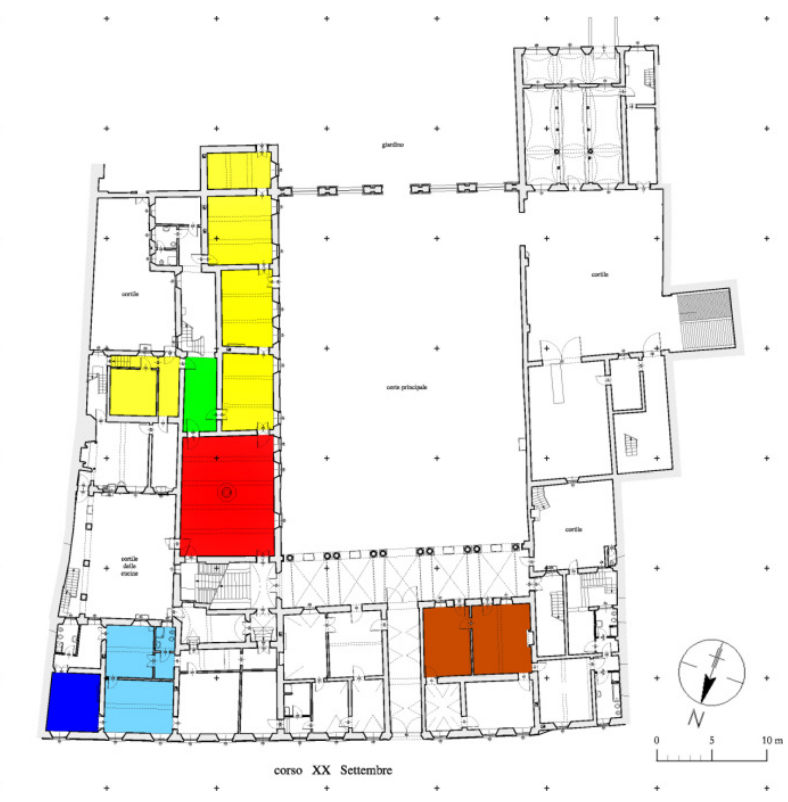

Figure 1: Ground floor plan of Palazzo Magio. In brown it's evidenced the floor from the late $15^{\text {th }}$ century; in cyan the floor decorated by Natali; in blue the floor hidden by a painted canvas ceiling; in red the floor with walnut joists; in yellow and green the reassembled floors, in green that with joists only.

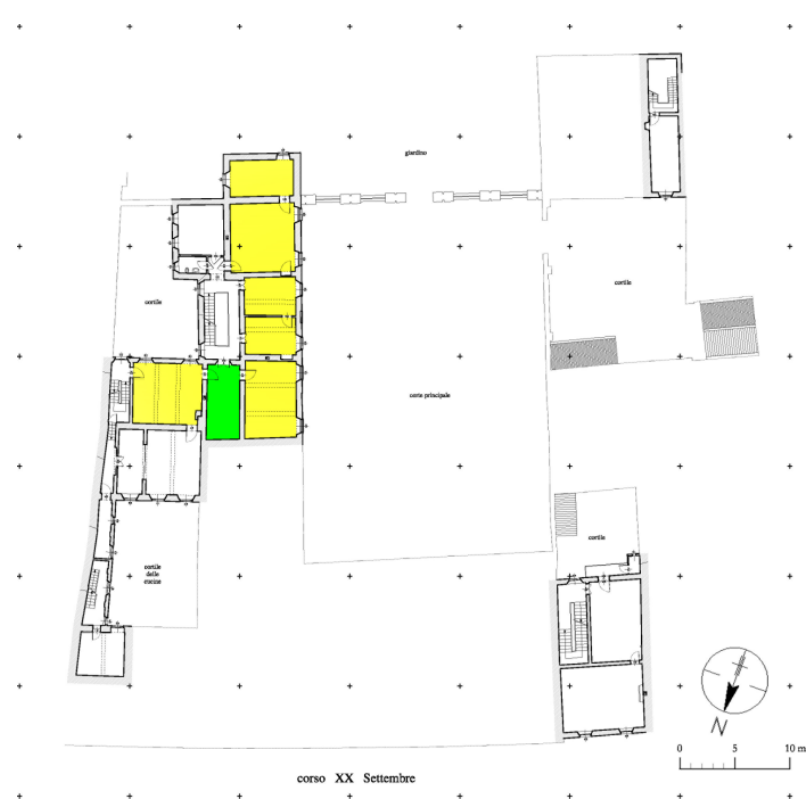

Figure 2: Mezzanine floor plan of Palazzo Magio. In yellow it's evidenced and green the reassembled floors, in green that with joists only. 


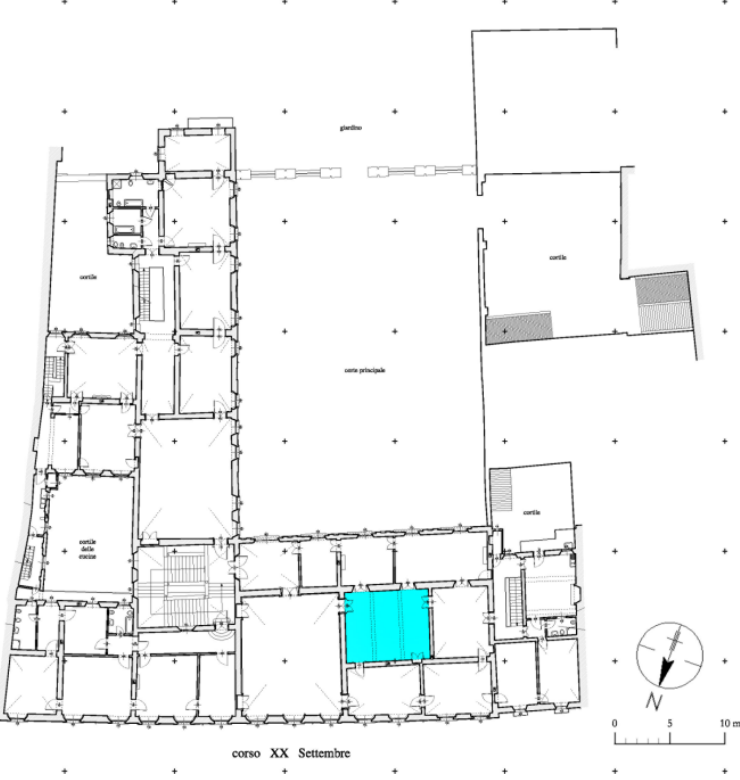

Figure 3: Main floor plan of Palazzo Magio. In cyan it's evidenced the floor with joists and planking renewed in the late $17^{\text {th }}$-early $18^{\text {th }}$ centuries.

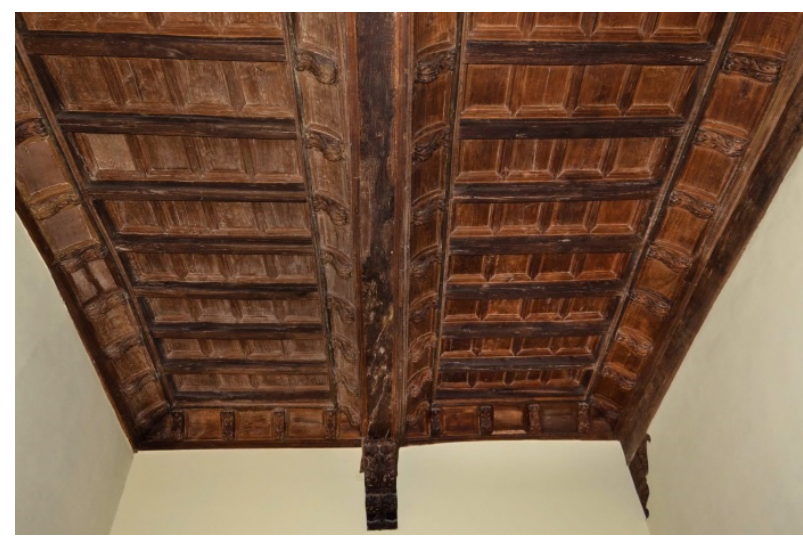

Figure 4: Timber floor from the late $15^{\text {th }}$ century, with corbels under the joists and concave bussole (photo by Giuliano Regis).

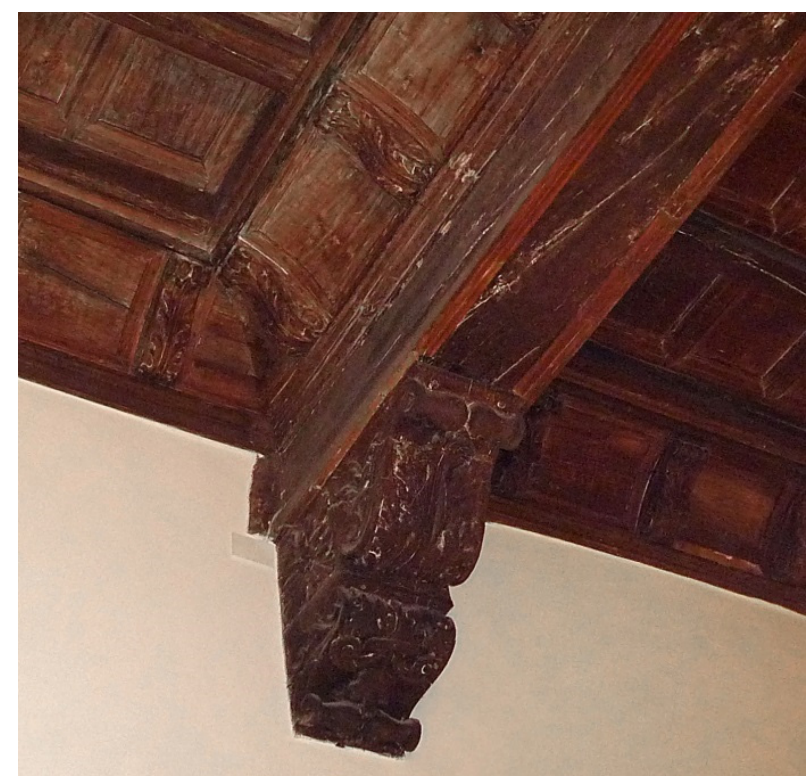

Figure 5: Detail of the floor in fig. 4.

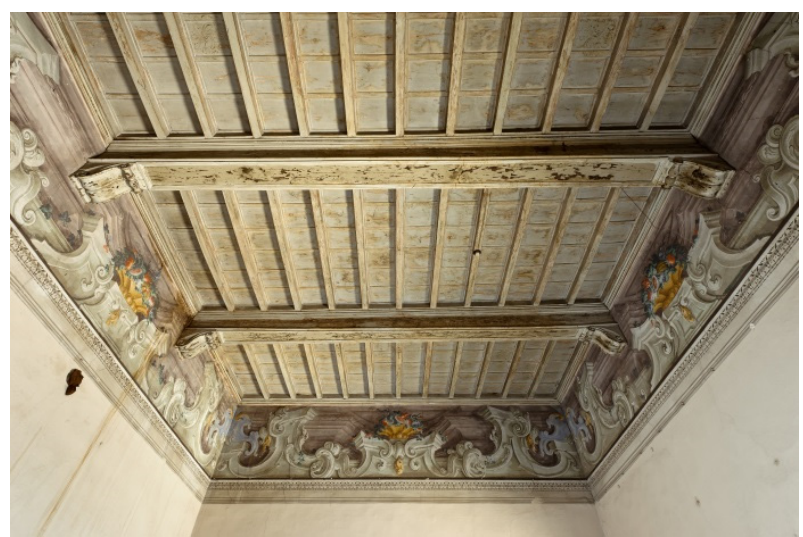

Figure 6: Timber floor with old girders; joists and planking were renewed between the late $17^{\text {th }}$ and the early $18^{\text {th }}$ centuries.

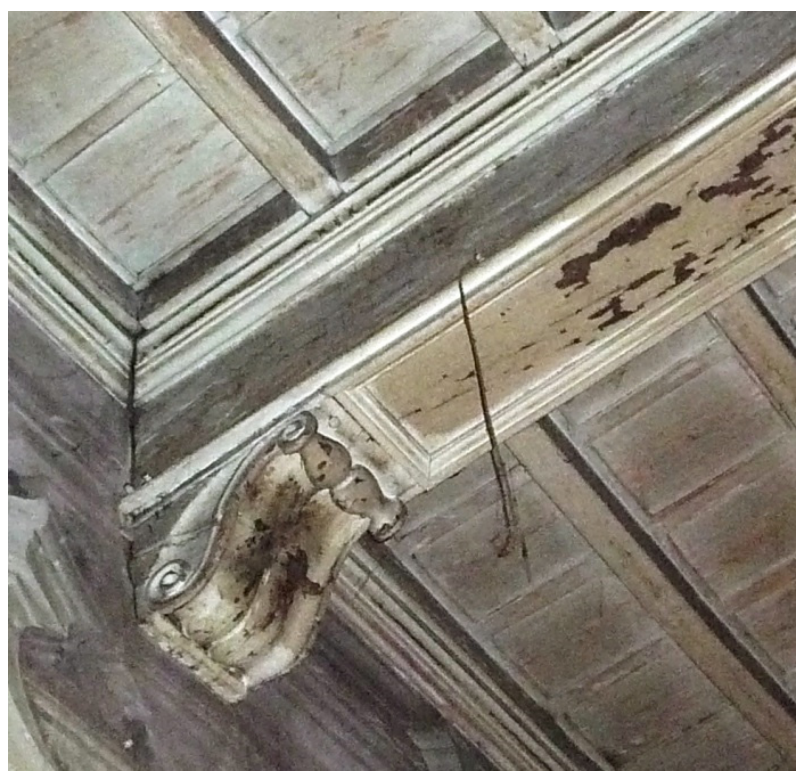

Figure 7: Detail of the floor in fig. 6.

In the east wing, another timber floor remains, it was decorated by Natali too, but three to four decades earlier, in the late $17^{\text {th }}$ century. In the adjoining room, only the two major beams are preserved, while joists and planking appear to have been replaced in an unspecified period, perhaps in the late $18^{\text {th }}$ century, much more likely in the late $19^{\text {th }}$ century, and the structure is covered by a painted canvas "ceiling" of the end from the $18^{\text {th }}$ century.

In the wing on the courtyard, instead, there is still a single large timber floor, of about $100 \mathrm{~m}^{2}$, with walnut joists and boards, which already existed in 1702 (Fig. 8).

In the other rooms on the ground and mezzanine levels, pre-existing floor structures - almost all of which have joists with the same dimensions as those in the other part of the building - have been reassembled, simplifying them, in particular without placing the bussole, so that the grooves aimed to house them are now in sight (Fig. 9). Perhaps they are those once present on the main floor in the wing along the street, towards the east, that were dismantled to build vaults, or perhaps the reused material comes from the older demolished buildings, that stood on the same area of the new building or in the main courtyard. The construction site takes place in two successive phases, a first around 1760 and a second 
within 1780. In the latter, a subfloor made with tavelle (flat bricks) replaces the wooden boards.

This sequence of transformations can be dated with certainty within a sufficiently limited time interval, the corresponding timber elements and their measures especially if compared with other examples of the same city - allow one to reconstruct accurately a single constructive event, but also to get a sense of more general dynamics for this type of artefacts.

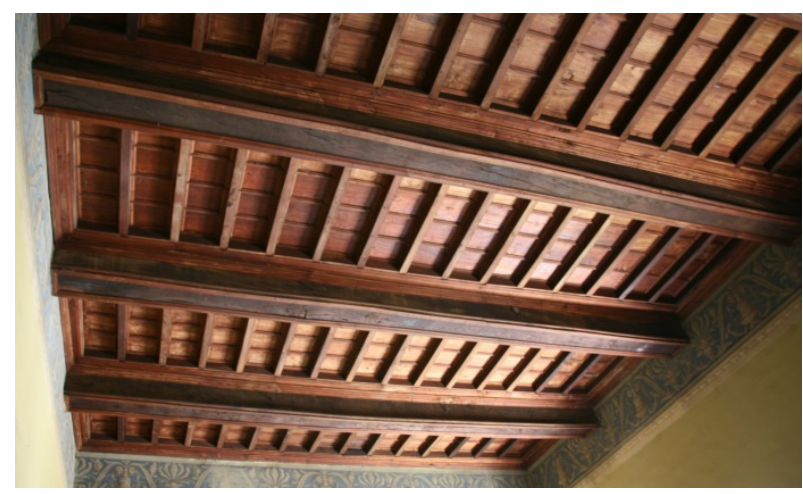

Figure 8: Floor from the late $17^{\text {th }}$ century.

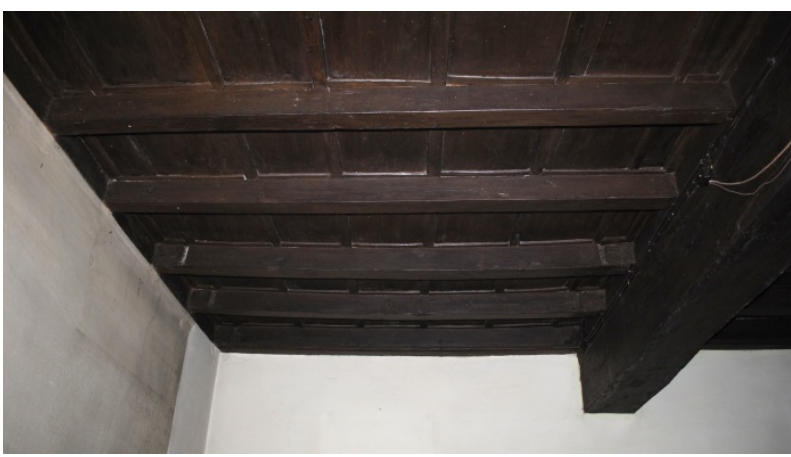

Figure 9: Floor rebuilt at the mezzanine in which the grooves for hosing the bussole are still visible.

To complete the diachronic repertoire of Cremonese timber floors, only the most elementary version is missing: the floor with concave bussole, that cover the whole height of joists and corbels, whose thickness is lower than in other types of floors (Figs. 10 and 11). Numerous examples of this type of floor still exist in the city, the oldest are preserved in civil and monastic buildings, and date back to about the mid- $15^{\text {th }}$ century.

The use of exposed timber floors on large rooms in which a high degree of finish was required lasts less than three centuries. From the second half of the $18^{\text {th }}$ century brick vaults were ordinarily used. If the building was not very modest and the rooms were not strictly utilitarian, when timber floors were still built, they were hidden by a ceiling made of reed mats and plaster, supported by a wooden frame, which often assumed a vaulted shape. This evolution is generalized in Italian civil construction, albeit in different times and ways between region and region, city and city. In Cremona the disappearance of the exposed timber floors also coincides with the lesser availability - at least in proportion to the demand - of the wood which ensured their quality, even the structural one: the local oak.

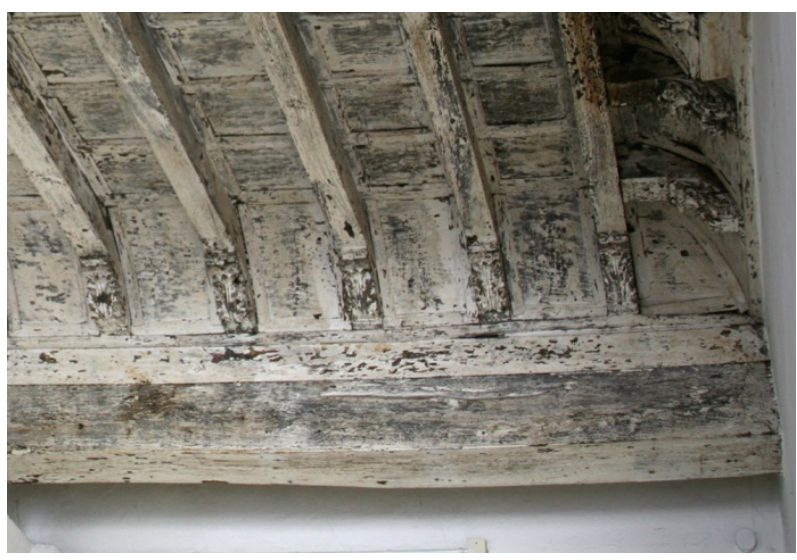

Figure 10: Floor with bussole covering joists and corbels from the late $15^{\text {th }}$ century (Palazzo Affaitati-Soldi).

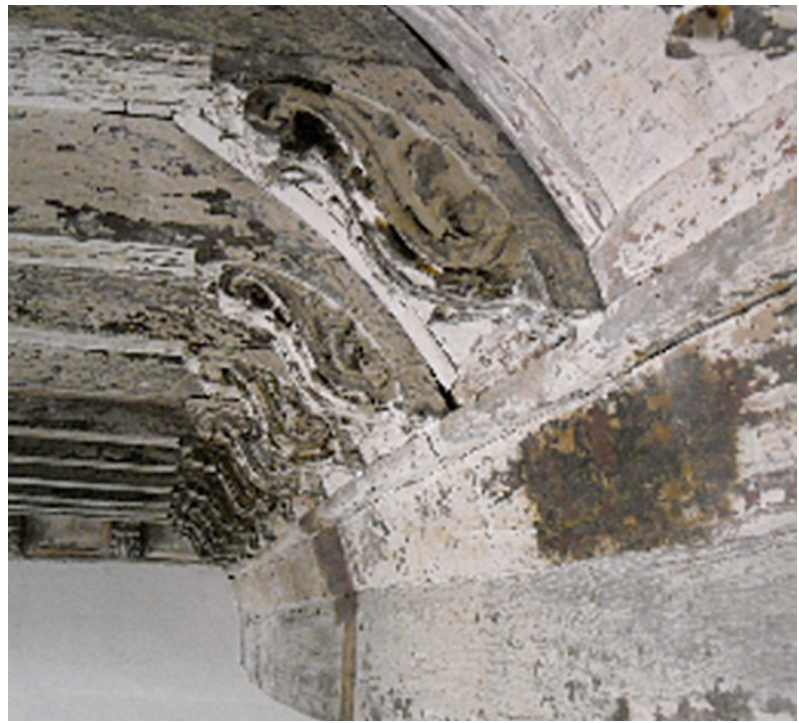

Figure 11: Detail of the floor in Fig. 9.

However, a direct cause and effect relationship cannot be identified: the checks made by Floriana Petracco (2011) show an increase in the wooded area between the Cadastre of Charles V (Jacopetti 1984), in the mid-16 ${ }^{\text {th }}$ century, and the Teresian Cadastre, in the first half of the $18^{\text {th }}$ century, but it is unlikely that the cultivation was directed towards the production of timber for structures, especially taking into account the time required for the growth of trees capable of providing the large trunks necessary for the girders.

\section{The literature and the institutional sources of the Modern Era}

Another circumstance is favourable: the Cremonese Alessandro Capra (circa 1610 - circa 1685), architect, military engineer, skilled machine builder (Dezzi Bardeschi, 1963; Olivato, 1976; Bellini, 1982), published - in various parts then collected in a single work - a sort of treatise, a collection in five "books" of the knowledge necessary for the activities of an engineer of his time, which extends from agriculture to construction, measurement techniques, geometry and machines (Capra, 1678), which enjoyed a fair amount of success even outside Cremona. The treatise is based on local 
construction practices and is quite detailed, even in metric terms.

The estimate of the existing trees in agricultural properties and the recommended dimensions in the buildings give a series of measures that find punctual correspondence in the preserved examples, starting from Palazzo Magio itself. In this way, we can overcome the shortcomings of another possible source, the Statutes of the city, which under the heading DCXLIX, of the 1578 edition, deal almost exclusively with the much more requested firewood (Statuta, 1578).

Capra describes the oaks as the only species suitable for beams for roofs and floors, while joists could also be made of the less expensive poplar, birch and mulberry timber. This subdivision was preserved over time and appears even more marked in the $19^{\text {th }}$ century documents analysed by Emanuela Carpani (2003), according to which in timber floors girders were almost always made with oak, joists and planking with poplar.

Capra almost never speaks of the length of the logs, but rather of their section: on average those from which boards must be obtained are long ten braccia (the Cremonese braccio - arm - is equal to about $48.35 \mathrm{~cm}$ and remained in use until 1781, when it was replaced by the Milanese braccio; Galosio, 1786), and have a net width between 10 and 15 ounces (i.e. from 40 to $60 \mathrm{~cm}$, being the ounce a twelfth part of the braccio) and a thickness of one ounce or two, and in this second case they are called tasselli. The height of the bordonali beams used for the roofs - is up to 8 ounces $(32 \mathrm{~cm})$ but their length would not exceed ten braccia, even if the logs are made from «big, straight and long» oaks. The sections of the joists are described in greater detail (3 ounces $\times 3.5$ or 4 ounces, $12 \mathrm{~cm} \times 14$ or $16 \mathrm{~cm}$ ) and it is said that they are obtained from the small oaks.

The measures indicated by Capra were probably those of the elements obtained squaring the logs by axing or sawing and then reducing them in four joists with the saw; it is, therefore, necessary to remember that - especially in the more refined floors, those for which, as already written, this type of study makes the most sense - the timber elements were further worked by planing the upper face to allow perfect support for the overlapping elements and usually even the bottom and sides to improve their appearance. The quantity of material subtracted by planing depended on various aspects (e.g. regularity of the previous woodworking); it is therefore not easy to define the dimensional loss connected to it. Given the processing techniques, what tolerance should be assumed in this case? The comparison between the measurements found in Palazzo Magio and the texts suggests an interval of about half an ounce, $2 \mathrm{~cm}$, which determines the increase or decrease of one unit.

Capra makes no mention of the import of timber, which would therefore be produced actually in the local countryside, not only for rural construction, but also for the limited city market. Perhaps, more simply, the substantial economic autonomy of large land properties is confirmed, as in the production of brick. An argued answer would require an accurate comparison between the vague indications of the Charles V Cadastre and the much more precise ones of the Teresian Cadastre, and, if possible, on the administration of a number of large agricultural estates.
In the building and demographic recovery that followed the plague of 1630 and the peace treaties of Westphalia (1648) and the Pyrenees (1659), the large exposed timber floors in monumental rooms were a rapidly declining practice, limited to cases in which it was justified by availability of spolia from demolished or renewed buildings, especially the less common and more expensive girders to be eventually integrated with new more easily available joists. Again, the substantial identity of size between the $15^{\text {th }}$ century and $17^{\text {th }}$ century elements suggests an analogy with bricks, which have not changed in size since the late Middle Ages (Landi, 2013). This uniformity facilitates re-use, and - even more than for brick - the measurements of the timber are a difficult balance between structural quality and rational use of the trunks of the same tree species.

These reasonable motivations are further supported by the fact that the share of self-consumption timber is probably high. Large landowners are also the major investors in the city and in documents the costs of building materials often emerge only indirectly and are quantified in the management or in the rental contracts of the rustic funds that provide them. Moreover, since they control the institutions they could act directly on the price, if they wanted to achieve a greater profit with the product that exceeds their needs. Even in the case of timber, there would therefore be no free market, no demand and supply capable of forming prices, but also of encouraging the modification of products, a real dialectic between producers and consumers, which either coincide or have highly unbalanced contractual powers. These summary considerations certainly have a reference time span, from the late sixteenth century to the early decades of the eighteenth century, a time interval that is actually not homogeneous, if not in the hegemony, both political and economic, of the citizen patriciate.

\section{Construction and reuse of timber floors from $17^{\text {th }}$ to $18^{\text {th }}$ century in a patrician palace}

In Palazzo Magio the surviving construction phases are distant in time, between the beginning of the $16^{\text {th }}$ century and the second half of the following century: the extremes - apogee and decline - of the use of timber floors. The centre distance of the beams and the dimensions of the elements (joists, moulds, bussole, corbels) that make up the $15^{\text {th }}$ century floor towards the loggia are similar to the other numerous examples known in the city. More checks would be needed, but the floors of Palazzo Affaitati, then Pallavicino di Busseto, Brumani - and subsequently Soldi - (Azzolini, 1996) are comparable with those of Palazzo Magio and referable to the dimensional indications given by Capra; in this palace, the joists have a width of 10.5 $\mathrm{cm}$ and a height of $12 \mathrm{~cm}$. In Palazzo Magio the span of the joists is $2.45 \mathrm{~m}$ (just over 5 braccia), but it becomes $1.90 \mathrm{~m}$ (4 braccia) if the corbels are taken into account; in Palazzo Affaitati-Soldi the span is $2.90 \mathrm{~m}$ ( 6 braccia), but becomes $2.20 \mathrm{~m} \mathrm{(4} \mathrm{1/2} \mathrm{braccia)} \mathrm{net} \mathrm{of} \mathrm{the} \mathrm{corbels} \mathrm{(Fig.} \mathrm{12).}$

The processing of the raw material imposes its logic, and tends to standardise. The transition between these floors and those of a century and a half later is hardly recognizable in the city, and the examples that can be dated with certainty to the end of the $16^{\text {th }}$ and early $17^{\text {th }}$ centuries appear as coffered ceilings of boards. They are rare and were expensive. According to Capra, who 
estimates eight different types of floors, they require twenty-four times more hours - two days for each quadretto (the square with the side of one braccio) - than the simpler floor, the one that has only cantinelle (i.e. trapezoidal laths) hiding from below the joints between the boards, which are simply placed on top of the joists, without realizing notches; twelve quadretti of this elementary floor could be made in a day. Another significant cost leap separates the floors framed with cantinelle from those framed with cornices (i.e. laths with cyma reversa mouldings); in this case laths are not only used to hide the joints between the boards, they are also put along the joists to complete the frame; we go from six quadretti to three quadretti per day. The floors on the ground floor of Palazzo Magio belong to this more expensive case. In reality, as it's clearly visible in the room whose ceilings are decorated with passasotto paintings (Fig. 13), the moulded laths are still very similar to those in the Renaissance floors and they contrast - much more than the simpler trapezoidal laths - with the continuous decoration of the planking, which spread at the end of the $17^{\text {th }}$ century.

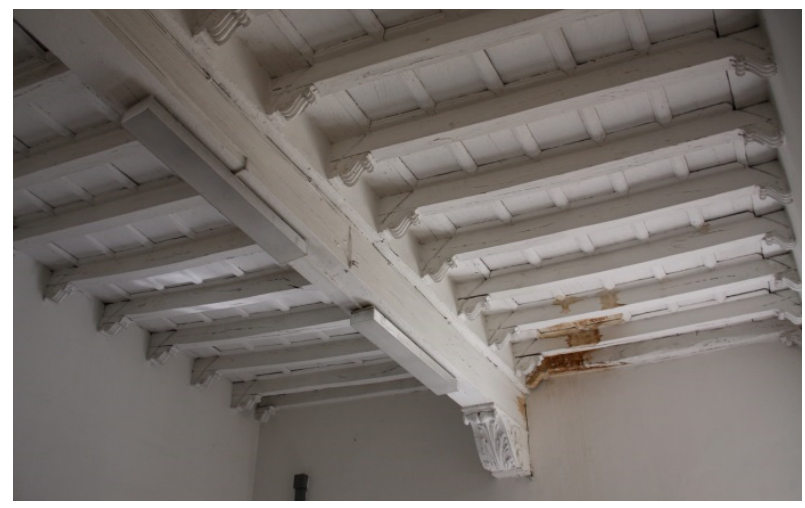

Figure 12: Timber floor in Palazzo Affaitati-Soldi.

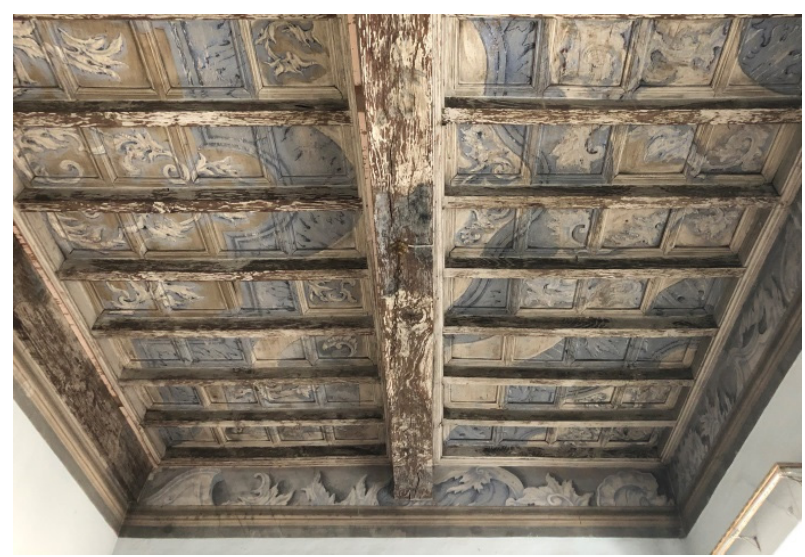

Figure 13: Timber floor in Palazzo Magio with passasotto painting.

This is perhaps the last step in a progressive simplification. Compared to the early $16^{\text {th }}$ century, the corbels under the girders and under the joists have disappeared, therefore the net spans increased. The double concave bussole have been replaced by a simple vertical board, also inserted from above into two grooves of decreasing depth made in the sides of the joists and by a horizontal board with moulding on the external side or by a simple moulded cornice, which runs along the walls and the beams just below the joists, to which it is nailed.
Other moulded cornices - the section of which is inscribed in an isosceles right-angled triangle, perhaps obtained from a solid wood the size of a joist - are inserted in the corners, connecting vertical and horizontal surfaces. The goal was to counter or hide the reciprocal movement between the elements, but at the same time, they wanted to convey an idea of coherence and order.

By simplifying, the floor is lightened, and at the same time, however, the admissible loads decrease: the sections of the joists do not change between the end of the $15^{\text {th }}$ century (ground floor towards the loggia) and the $17^{\text {th }}$ century (floor of the hall, always on the ground floor, towards the courtyard), however, the spacing (centre to centre distance) between the joists and their clear span change, since the spacing between the beams remains almost constant, but there are no longer the corbels. The span of the joists goes from about $1.90 \mathrm{~m}$ net of the corbels in the $15^{\text {th }}$ century floor to about $2.40 \mathrm{~m}$ in the large $17^{\text {th }}$ century floor with walnut joists, that is, from 4 to 5 braccia.

In this case, the actual spans are determined by the dimensions of the individual rooms (which are affected by the size of the lot) and, consequently, by the distances between the walls, as well as by the size of the available joists, to be obtained, according to Capra, from logs about $4.80 \mathrm{~m}$ long. Given this length, although it has not been possible to carry out direct investigations, we can hypothesize that the joists could be continuous on two spans. Despite referring to the use of "small" oaks, four joists already corresponded to a log of about $36-40 \mathrm{~cm}$ in diameter at its smaller end.

In the floors of Palazzo Magio, the depth/span ratio of the joists is always between $1 / 18$ and $1 / 23$, and it's $1 / 24$ in the analysed case of Palazzo Affaitati, as suggested by various authors over time (Scamozzi, 1615; Patte, 1777; Rondelet, 1810; Borgnis, 1823). In the floor with walnut joists, the elements have larger dimension than the others: the depth/span ratio is the biggest $(1 / 18)$, an aspect that leads us to hypothesize that the lower resistance of walnut wood compared to oak - in addition to the slightly greater spacing of the joists - was taken into account. Only in two floors with only joists and without beams, the span of the span is significantly greater $(3.20$ $\mathrm{m})$ : those that cover two overlapped rooms whose dimensions were predetermined by those of a medieval cellar and therefore, at least in part, by the persistence of the walls above ground. These floors were also dismantled and reassembled - as evidenced by the grooves of the bussole which are now visible since they were not put back in place - probably in the same rooms in which they were located, following the change in height of the storeys. These are the only floors in which oak joists have significantly different dimensions $(10 \mathrm{~cm} \times 14 \mathrm{~cm})$ and are probably obtained by planing the larger joists suggested by Capra ( 3 ounces $\times 4$ ounces, $12 \mathrm{~cm} \times 16$ $\mathrm{cm}$ ); the choice of using larger elements could have been determined by the fact that with joists of the size used in the other floors, the limit of $1 / 24$ would have been exceeded, reaching 1/27.

Observing what seems to be an almost perfect dimensional correspondence between the lengths of the reused elements and the dimensions of the rooms, it seems possible to propose the hypothesis that it was the size of the material available - coming from the demolitions - that provided the basis for determining the 
dimensions of the rooms built in the $18^{\text {th }}$ century. This hypothesis must not seem too odd, since even some treatise writers suggest defining the dimensions of the rooms according to those of the timber available (Valadier, 1831). This would better explain the unusual dimensional progression of the rooms towards the garden of Palazzo Magio, not bound by the common rule that the larger size of a room becomes the diagonal of the adjacent one.

The rooms of Palazzo Magio have sequences of between ten and sixteen joists. In the absence of a commercial circuit that would ensure an absolute homogeneity of the materials supplied, the adjustment in the construction site could be complex; the differences in spacing between the beams of the same floor can thus be more easily explained. The spacing between the joists also varies; the most accentuated difference can be seen in the case of the large $17^{\text {th }}$ century floor of the room overlooking the courtyard is probably connected to the wood species, not oak but walnut, joists and boards are made of; the latter also seem to have greater width, probably to keep a square shape to the framing of laths covering the joints of the boards and placed along the joists. This has probably been an occasional purchase, or availability in the Magio landholdings. Capra distinguishes walnut in some varieties, and identifies one intended for carriages or agricultural equipment, which required particular solidity, and therefore justifies this - in any case singular - use in construction.

Conversely, between the $15^{\text {th }}$ and late $17^{\text {th }}$-early $18^{\text {th }}$ centuries, the variation in the spacing of the laths covering the joints of the planking appears to be less significant and less systematic: necessarily the width of the boards had to be been more constant.

In theory, the increase in the spacing of the joists should always translate into a greater width of the boards, to keep a square shape to the laths framing; in reality, the numerous necessary adjustments determine a visible difference only when the distance between the joists is significantly increased, but these are then rough repairs of the full nineteenth century.

The floors reused at the end of the $18^{\text {th }}$ century require particular attention to reconstruct the extent of the adaptations undergone, and to trace their possible original late $17^{\text {th }}$ century construction. The most evident modification is that the boards between the joists - in which the grooves remain empty - have not been reassembled, as the underlying horizontal moulded boards or cornices. In fact, the most difficult parts to remove intact and to reassemble are missing.

Furthermore, there are no moulded, but simple trapezoidal laths. The lack of dendrochronological investigations, and of absolute dating of single wooden elements makes the measures and the traces of processing decisive for the comprehension of the construction events.

\section{Further development of the research}

The research presented is open to further development. These can be directed on the one hand towards a greater detail of the surveyed measurements and towards their correlation with the level of finish of the joists' surfaces, on the other hand towards the extension of the metric and construction surveys to a greater number of floors. A systematic analysis - also statistical - of the detected dimensions could allow estimating with good approximation the dimensional tolerance of the commercial timbers, the dimensional losses due to the planing operations and the final dimensions of the elements; the extension to a significant number of cases could also make it possible to detect an evolution over time of the various quantities obtained from the surveys or from the analyzes.

\section{Conclusions: recurrences and differences}

Generally, the usefulness of a detailed and precise survey of the individual elements has complex purposes. It has ancient measurements as a reference, recognizes the allowed tolerances, variations and presumable adjustments at the time of execution, thus allowing to reconstruct the details, the interaction between local availability and processing of the material and sizing of the elements to be made. A purely morphological analysis - even if it detects a dimensional identity - is of little significance, especially if we take into account that its most evident reference, the mouldings, are part of a vocabulary that has been substantially shared throughout Europe since the Renaissance. Cyma recta and reversa, fillet, cavetto, ovolo, etc. and their tracing are part of the notions of elementary design that all specialized craftsman owned, when the particularity of the case didn't justify the intervention of a professional, often also an entrepreneur, or of the commissioner with deeper artistic culture. Only this vast and generic common background makes it clear why the similarities that can be found in these details in different and distant regions since the $16^{\text {th }}$ century are very numerous. A "mensiochronology of wooden elements" - no less than their "chronotypology" becomes all the more uncertain and requires more sophisticated criteria for periods in which cultural exchanges increase and the ornamentation is codified by treatises, which the press makes more and more available.

However, a less sophisticated utility is not lacking: if we understand the sizing methods and tolerances, if we go back even to the less immediately visible construction nodes (as it is essential to establish the also metric correct representation of numerous details) real structural models can be established, obviously in well-defined times and contexts. Taking into account the tolerances, it is possible to establish validity ranges, including dimensional ones, of these models. Therefore significant dimensional discrepancies with respect to ordinary practice would allow us to understand the specificity of a given floor and encourage deepening the investigations to better understand the causes of this "anomaly" (Zamperini, 2013).

On the basis of some common peculiarities, individual cases can be traced back to these models and they can simplify and above all correctly orient each type of verification. The uncertainty and arbitrariness not only of the structural calculation, but also of the surveys that support it are too widespread; it is therefore necessary to counteract this superficiality - naturally, given the field of study - in a "constructive" way. 


\section{Acknowledgements}

This work was supported by Fondazione Cariplo ("Patrimonio culturale per lo sviluppo") in the framework of the action plan "Il Palazzo di Città: formazione, documentazione e innovazione per Cremona e il suo Distretto Culturale" (project no. 2016-2241), led by the Municipality of Cremona with the scientific partnership of Politecnico di Milano - Dipartimento di Architettura e Studi Urbani.

\section{References}

Azzolini, L. (1996). Palazzi del Cinquecento a Cremona. Cremona, Italy: Turris.

Baroni, S., \& Travaglio, P. (2011). Gli apparati decorativi di Palazzo Magio Grasselli a Cremona. In Landi, A.G. (Ed.), Patrizi, notabili, costruzione della città: fabbrica e tutela di palazzo Magio Grasselli a Cremona. Torino, Italy: Allemandi (pp.117-153).

Bellini, A. (1982). Alessandro Capra, ingegnere cremonese del '600 e trattatista di architettura civile. Cremona, Italy: Biblioteca Statale e Libreria Civica.

Biffi, G. B. (1988). Memorie per servire alla storia degli artisti cremonesi (L. Bandera Gregori Ed.). Annali della Biblioteca statale e libreria civica di Cremona, 39(2) Cremona, Italy: Linograf.

Borgnis, G. A. (1823). Traité élémentaire de construction appliquée à l'architecture civile. Paris, France: Bachelier.

Bouticourt, E. (2016). Charpentes méridionales. Construire autrement: le midi rhodanien à la fin du Moyen Age. Arles, France: Honoré Clair.

Capra, A. (1678). La nuova architettura famigliare. Bologna, Italy: Giacomo Monti.

Carpani, E. (2003). A fior d'arte. Il cantiere cremonese preindustriale. Milano, Italy: LED.

Dandria, S. (2010). Commercio del "legname da opera" nella valle dell'adige fra XIII e XVII secolo: assortimenti e impieghi in relazione alla diffusione delle travi composte. Doctoral thesis. Milano, Italy: Politecnico di Milano.

Dezzi Bardeschi, M. (1963). Su Alessandro Capra, ingegnere e architetto cremonese, e sul suo trattato d'architettura. Studi secenteschi, 4, 45-79.

Galosio, G. A. (1786). La perizia e l'agrimensura. Cremona, Italy: Francesco Gaetano Ferrari.

Grimoldi, A., Landi, A. G., \& Facchi, E. (2019). Re-employed, transformed or preserved. The wooden beam floors in palazzo Magio Grasselli in Cremona. In J. M. Branco, E. Poletti, \& H. S. Sousa (Eds) SHATiS'19 - 5th International conference on structural health assessment of timber structures, Guimarães, Portugal: University of Minho (pp. 189198).

Jacopetti, I. N. (1984). Il territorio agrario-forestale di Cremona nel catasto di Carlo V (1551-1561). Cremona, Italy: Biblioteca Statale e Libreria Civica - Camera di commercio, industria e agricoltura.

Landi, A. G. (2011). Riforme edilizie in una dimora aristocratica cremonese: palazzo Grasselli fra civitas e urbs. In Landi, A. G. (Ed.), Patrizi, notabili, costruzione della città: fabbrica e tutela di palazzo Magio Grasselli a Cremona. Torino, Italy: Allemandi (pp. 33-116).

Landi, A. G. (2013). I mercati del laterizio a Cremona tra età medievale e XIX secolo. Premesse all'avvio di un'indagine mensiocronologica. Materiali e strutture. N. S., 2 (4), 18-30.

Mannoni, T., \& Milanese, M. (1988). Mensiocronologia. In Archeologia e restauro dei monumenti, "Quaderni del Dipartimento di Archeologia e Storia delle Arti. Sezione Archeologica. Università di Siena", 12-13, Firenze, Italy: All'Insegna del Giglio (pp. 383-402).

Olivato, L. (1976). Alessandro Capra, In Dizionario Biografico degli Italiani, 19, Roma, Italy: Istituto della Enciclopedia italiana.

Patte, P. (1777). Cours d'architecture ou traité de la décoration, distribution \& construction des bâtiments commencé par feu J. F. Blondel [...] et continué par M. Patte [...]. Tome sixième. Paris, France: Chez la Veuve Desaint.

Petracco, F. (1998). L'arte del costruire a Cremona: maestranze, materiali e tecniche nei secoli 16-17. Tesi di dottorato, Milano, Italia: Politecnico di Milano.

Petracco, F. (2011). II legno a Cremona nei secoli XVI-XVIII: primi cenni sulla coltivazione, i formati e i suoi molteplici utilizzi. Liuteria Musica e cultura. N.S., 6(2), 35-45.

Pittaluga, D. (2009). La mensiocronologia dei mattoni. Genova, Italy: EClg.

Rondelet, J. (1810). Traité théorique et pratique de l'art de batir. Tome quatrieme. Première partie. Charpente. Paris, France: Chez l'auteur, Enclos du Panthéon.

Scamozzi, V. (1615). L'idea della architettura universale. Parte seconda. Venice, Italy.

Statuta, (1578). Statuta civitatis Cremonae. Cremona, Italy. 
Valadier, G. (1831). L'architettura pratica dettata nella scuola e cattedra dell'insigne Accademia di S. Luca. Tomo II. Roma, Italy: Rogrué e Catesi.

Zamperini, E. (2013). The study of timber structures base on in situ investigation. Advanced Materials Research. 778, 97104. https://doi.org/10.4028/www.scientific.net/AMR.778.97 